\title{
The density of feral honey bee (Apis mellifera) colonies in South East Australia is greater in undisturbed than in disturbed habitats
}

\author{
Eloise M. Hinson ${ }^{1}$, Michael DunCAN ${ }^{2},{\text { Julianne } \operatorname{Lim}^{1} \text {, Jonathan Arundel }}^{3}$, \\ Benjamin P. OLDROYD ${ }^{1}$

\begin{abstract}
${ }^{1}$ Behaviour and Genetics of Social Insects Laboratory, School of Biological Sciences A12, University of Sydney, Sydney, NSW 2006, Australia

${ }^{2}$ School of Science and Health, University of Western Sydney, Richmond Campus, Locked Bag 1797, Penrith, NSW 2751, Australia

${ }^{3}$ Department of Infrastructure Engineering, University of Melbourne, Melbourne, VIC 3010, Australia
\end{abstract}

Received 22 September 2014 - Revised 27 October 2014 - Accepted 5 November 2014

\begin{abstract}
Apis mellifera is an important pollinator but is sometimes associated with adverse effects on natural ecosystems. We surveyed pairs of disturbed and undisturbed sites across three biomes in South East Australia. We used pheromone lures to trap drones, genotyped the drones to infer the number of colonies within flight range and then estimated colony densities using synthetic sampling distributions. Estimated colony densities ranged from 0.1 to 1.5 colonies $\mathrm{km}^{-2}$ and significantly lower in agricultural land relative to national parks. We suggest that colony density may be lower in disturbed than 'natural' areas due to the reduced availability of nest sites and possibly pesticide usage. Because the number of colonies recommended for adequate pollination is $100-1000$ colonies $\mathrm{km}^{-2}$, there are insufficient bees to provide optimal crop pollination in the areas we surveyed.
\end{abstract}

feral honey bees / colony density / microsatellite haplotypes / population size

\section{INTRODUCTION}

Honey bees, Apis mellifera, were introduced into Australia in 1822 (Hopkins 1886), and a significant commercial beekeeping industry has subsequently developed, based on honey production and paid pollination services (Benecke 2007). Australia also has a large population of feral honey bees (Paton 1996; Oldroyd et al. 1997; Arundel et al. 2014). It is often assumed by farmers that

Electronic supplementary material The online version of this article (doi:10.1007/s13592-014-0334-x) contains supplementary material, which is available to authorized users.

Corresponding author: B. Oldroyd, boldroyd@bio.usyd.edu.au Manuscript editor: Stan Schneider feral populations are sufficient to ensure adequate crop pollination in many agricultural systems (Gordon and Davis 2003), although this assumption is usually contradicted by empirical studies (reviewed in Free 1970; McGregor 1976; Roubik 1995; Delaplane and Mayer 2000). Honey bees may also play a pollination role in remnant bushland, where native pollinators are rare or extinct (Paton 1993; Day et al. 1997; Corlett 2001; Dirk 2001; Lomov et al. 2010).

Despite the many benefits of honey bees, feral honey bees may have negative impacts on some native biota. Feral honey bees may promote the spread of weedy exotics by increasing seed set (Butz Huryn 1995; Richardson et al. 2000; Goulson and Derwent 2004; Simpson et al. 2005) and reduce the pollination of some native plants (Taylor and Whelan 1988; Vaughton 1996; 
Paton 1997; Gross and Mackay 1998; Goulson 2003). Feral bees can compete with native vertebrates and invertebrates for floral resources, nest sites and in some cases water (Saunders et al. 1982; Oldroyd et al. 1995; Wood and Wallis 1998; Gross 2001). Nonetheless, most studies of honey bee-native bee competition have shown that native bee populations stand up well to competition from honey bees (e.g. Sugden et al. 1996; Paini et al. 2005; Roubik and VillanuevaGutierrez 2009).

It is often important to have reliable estimates of the density of feral honey bee colonies. First, in some areas where there is intensive horticulture or field crops such as canola, crop pollination is optimised when the density of colonies is $1-10$ colonies ha ${ }^{-1}\left(100-1000\right.$ colonies $\mathrm{km}^{-2}$ ) (Delaplane and Mayer 2000; Breeze et al. 2014). We do not know if feral and domestic colonies approach this density, though it seems unlikely over broad scales. Equally, intensive agriculture and horticulture is generally confined to small areas, so it is rare that the density of honey bee colonies needs to be so high over broad areas. Second, in natural environments, the extent of competition with native biota likely depends on density (Oldroyd et al. 1994). For this reason, it is desirable to have estimates of the density of feral colonies in conserved areas. Finally, feral colonies may serve as a source or reservoir for honey bee parasites and diseases. There is high risk that Varroa destructor, a parasitic mite that attacks honey bee brood and spreads bee viruses, will invade Australia in the future (Oldroyd 1999; Rinderer et al. 2013). Varroa is therefore of significant biosecurity concern to the beekeeping industry. An effective biosecurity response to an incursion of Varroa will require eradication of feral honey bee colonies across broad scales. Assessing the feasibility of such an eradication programme will require credible estimates of the density and distribution of feral colonies in relevant areas in which the incursion is detected.

The reproductive biology of the honey bee provides a novel means by which to estimate the density of honey bee colonies within a particular landscape. Male honey bees gather in mating leks in which drones from colonies within a $7-\mathrm{km}$ radius (Ruttner and Ruttner 1972) and gather in flight in well-defined areas called drone congregation areas (DCAs) (Loper et al. 1992). When a virgin queen approaches a DCA, drones are attracted by her Queen Mandibular Pheromone (QMP), of which E-9-oxo-2-decenoic acid (9ODA) is the major component (Free 1987). Drones can detect 9-ODA over a range of about 100 m (Winston 1987; Brockmann et al. 2006). Large numbers of drones can be captured at DCAs by means of an aerial trap suspended from a helium balloon and baited by lures impregnated by 9-ODA (Williams 1987; Koeniger et al. 1989; Baudry et al. 1998).

Drones caught in a trap can be genetically analysed to infer the number of unique colonies that contributed drones to the DCA. A set of tightly linked microsatellite loci are used to genotype the drones. If there is no genetic recombination between the loci, each diploid queen produces haploid drones of just two alternative haplotypes (Moritz et al. 2008). Thus, provided that the sample size is sufficient, the number of colonies within drone flight range of a DCA can be estimated by dividing the number of unique drone haplotypes observed in the sample by two.

Once the number of unique colonies within range of the sampled DCA has been estimated, the underlying colony density can be inferred. Under the assumption that drones fly an average of $900 \mathrm{~m}$ (Taylor and Rowell 1988), the area surveyed by a drone trap is approximately $2.5 \mathrm{~km}^{2}$ (Moritz et al. 2007, 2008; Jaffé et al. 2010). However, the flight range of drones and queens is plastic (Peer 1957; Neumann et al. 1999; Jensen et al. 2005), and the $2.5-\mathrm{km}^{2}$ mating flight range is likely a significant underestimate. Rather than trying to infer the density of colonies based on assumptions about drone flight range, a more robust approach may be to use agent-based simulations to generate synthetic sampling distributions (Arundel et al. 2013).

Here, we use the drone capture method of Jaffé et al. (2010) to estimate densities of feral honey bee colonies in matched disturbed and undisturbed sites across three biomes in South East Australia. We infer the density of feral honey bee colonies in agricultural and conserved ecosystems and assess the impact of land use on the density of feral colonies. 


\section{METHODS}

\subsection{Study locations}

We selected three national parks located within three broadly different ecological regions of south east Australia (Table I; Figure 1). For each park, we identified two suitable sampling sites within the park and paired each of these relatively undisturbed sites with a disturbed site outside the park in an area cleared for agriculture. Undisturbed and disturbed sites were separated by $>15 \mathrm{~km}$. Drones were sampled in February-March, 2011 using an aerial trap (Williams 1987).

\subsubsection{Region 1: Barrington Tops}

Barrington Tops National Park comprises some of the last remaining subtropical Gondwanan Rainforest in New South Wales (NPWS 2010). Within the park elevations range from 300 to $1500 \mathrm{~m}$, the annual mean temperature is $10-24{ }^{\circ} \mathrm{C}$ and the mean annual rainfall is $1500 \mathrm{~mm}$. Our first study site was situated at the southern end of the park alongside the Allyn River. This site is wet subtropical forest approximately $400 \mathrm{~m}$ above sea level. Site two was located at Gloucester Tops, an area of dry sclerophyll forest approximately $900 \mathrm{~m}$ above sea level. Table I gives the precise locations of the sampled DCAs.

The forest surrounding Barrington Tops National Park is highly fragmented by timber extraction and clearing for cattle grazing (NPWS 2004). We selected Stratford Park, located in the centre of the township of Stratford and Monkerai Road as matching disturbed sites for Barrington tops (Table I).

\subsubsection{Region 2: Weddin Shire}

The woodland communities within Weddin Mountains National Park protect some of the last remnants of the Central Western Slopes biome (NPWS 1995). Lying between 400 and $700 \mathrm{~m}$, this region receives an average annual rainfall of $620 \mathrm{~mm}$ and average temperatures ranging from 3 to $30^{\circ} \mathrm{C}$. Within the park, we sampled the feral bee population near Ben Halls Cave camp ground in the north west of the park and Holy Camp situated in the north east (Table I).
Outside the park, $>90 \%$ of the land is cleared for grazing and cropping (Benson et al. 2010). Our matching disturbed sites were near the townships of Tyagong and Grenfell (Table I).

\subsubsection{Region 3: Wimmera}

The semi-arid Lowan Mallee biome is an area of low rainfall and low elevation (70-90 $\mathrm{m}$ above sea level). Our undisturbed sites were located within Wyperfeld National Park. The vegetation is predominately short (5-8 m) multi-stemmed Eucalyptus woodland and heathland dominated by Banksia ornata. Most trees within the park are too small to provide cavities suitable for honey bees to nest in, but stands of red gum (Eucalyptus camaldulensis) and black box (Eucalyptus largiflorens) that fringe Outlet Creek in the south east of the park provide well-developed hollows suitable for nesting by honey bees and native vertebrates (Oldroyd et al. 1994). The feral honey bee population in this riparian woodland has been intensively studied (Oldroyd et al. 1994, 1995, 1997; Arundel et al. 2014), providing a measure by which to evaluate the effectiveness of drone trapping for estimating the size of feral honey bee populations.

The area surrounding the east side of the park has largely been cleared for dryland cropping and grazing. Due to extensive water extraction from the Wimmera River system, Lake Albacutya (and Outlet Creek) have not seen flows since 1980. The riparian woodland is therefore in decline because it lacks the periodic flooding required for seed germination and seedling establishment (George et al. 2005; Souter et al. 2010). We chose the edge of Lake Albacutya as one disturbed site for sampling drones. The second disturbed site was located near a remnant patch of mallee surrounded by cleared agricultural land.

\subsection{Sampling drones}

At each site, we selected a location that appeared suitable for a drone aggregation: that is a location adjacent to a conspicuous geographical landmark, typically a tree line, abutting an open space (Ruttner and Ruttner 1972). Drones were collected using a drone trap elevated using a $100 \mathrm{~g}$ helium-filled weather balloon (Williams 1987). Both the balloon and the drone trap were attached to a retractable nylon fishing line so that 


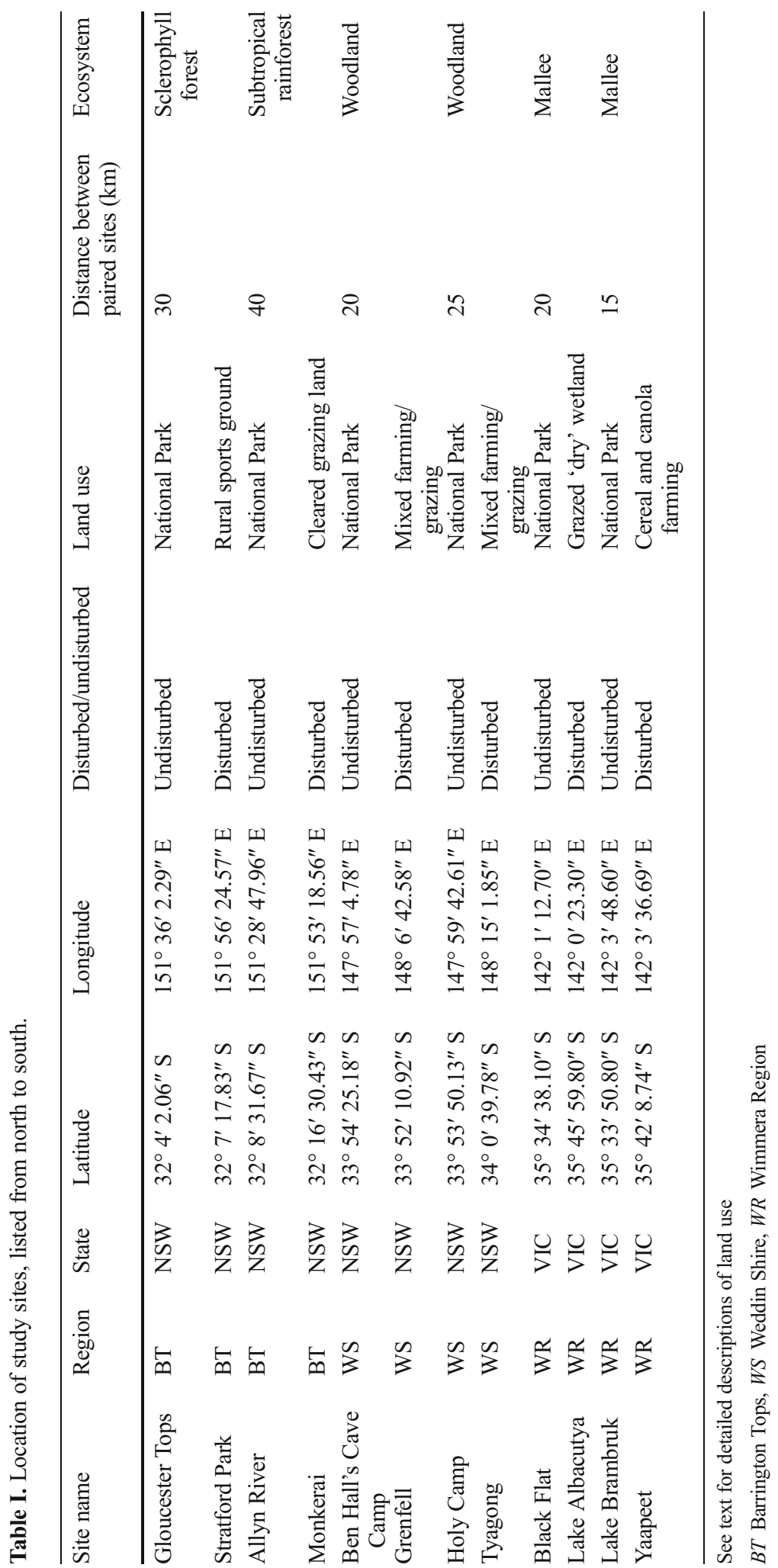


the trap could be transported and elevated to variable heights at the sampling locations. Inside the trap, we attached ten blackened cigarette filters to act as dummyqueen lures (Williams 1987). Each lure was baited with one queen equivalent $(20 \mu \mathrm{L})$ of synthetic E-9-oxo-2-decenoic acid (9-ODA; Phero Tech, Delta, Canada) that had been prepared as a solution of $21 \mathrm{mg}$ 9-ODA in $1 \mathrm{~mL}$ 2-propanol and $1 \%$ ultrapure deionised water.

We sampled drones between 12:00 and 17:00 on days that were suitable for drone flight — dry, not windy and $>18{ }^{\circ} \mathrm{C}$. Drones were caught $10-40 \mathrm{~m}$ above the ground. The ease of catching drones and the number of drones captured varied greatly among sites (Table II). We aimed to capture $100+$ drones at each site. We often achieved this within $15 \mathrm{~min}$, but where drones were difficult to catch, we increased sampling effort to two to three afternoons. We stored captured drones in ethanol and kept them frozen at $-20{ }^{\circ} \mathrm{C}$ until DNA extraction.

\subsection{Extraction of DNA}

DNA was extracted from one to two hind legs of each drone using a standard Chelex protocol (Walsh et al. 1991). Legs were added to $0.4 \mathrm{~mL}$ of $5 \%$ Chelex solution in a 1-mL centrifugable 96-well plate (Greiner Bio-One, Applied Biosystems). The leg tissue was homogenised by adding a stainless steel bead to each well and inserting the plate into a TissueLyser (Qiagen) for $10 \mathrm{~min}$ at $25 \mathrm{~Hz}$. Samples were then boiled for $15 \mathrm{~min}$, and the tissue was precipitated by centrifugation for $1 \mathrm{~h}$ at $4300 \mathrm{rpm}$ at $4{ }^{\circ} \mathrm{C}$. Supernatants $(200 \mu \mathrm{L})$ were transferred into $600 \mu \mathrm{L}$ 96-well plates (Axygen,

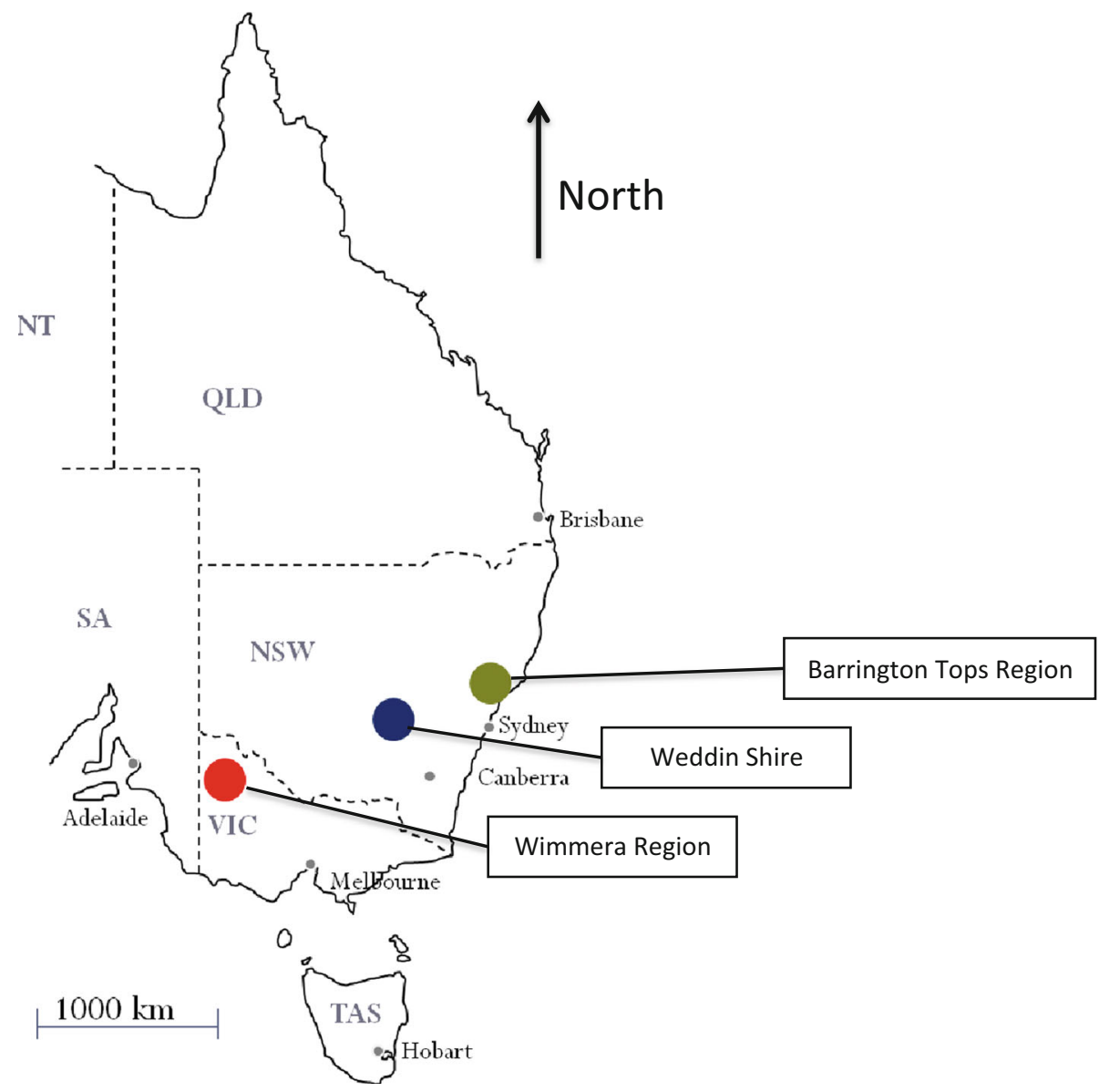

Figure 1. Map of East Australia showing the sampling regions in New South Wales and Victoria. 
Applied Biosystems) and stored at $4{ }^{\circ} \mathrm{C}$ until needed for polymerase chain reactions (PCR).

\subsection{Amplification of genomic DNA}

All drone samples were genotyped at six tightly linked $(<1 \mathrm{cM})$ microsatellite loci on chromosome three: UN397, SV181, UNEV5B, K0326, K0362 and UN042 (Solignac et al. 2003). The microsatellite target sequences were amplified in two triplex PCRs. Triplex 1 consisted of $0.05 \mu \mathrm{L}$ of forward and reverse primer for UN397, $0.03 \mu \mathrm{L}$ of forward and reverse primer for SV181 and $0.02 \mu \mathrm{L}$ of forward and reverse primer for UNEV5B, along with $0.125 \mu \mathrm{L}$ each of dATP, dTTP, dCTP and dGTP, $0.4 \mu \mathrm{L} 25 \mathrm{mM} \mathrm{MgCl}{ }_{2}, 0.25 \mu \mathrm{L} 50 \%$ glycerol, $0.5 \mu \mathrm{L} 10 \times$ TAQ-Ti polymerase reaction buffer (Fisher Biotec), $0.04 \mu \mathrm{L}$ TAQ-Ti DNA polymerase (Fisher Biotec), $2.11 \mu \mathrm{L} \mathrm{H}_{2} \mathrm{O}$ and $1 \mu \mathrm{L}$ genomic DNA. Triplex 2 consisted of the same reagents as for triplex 1 except for the primer and $\mathrm{H}_{2} \mathrm{O}$ volumes which were: $0.05 \mu \mathrm{L}$ of forward and reverse primer for $\mathrm{K} 0326,0.03 \mu \mathrm{L}$ of forward and reverse primer for $\mathrm{K} 0362,0.03 \mu \mathrm{L}$ of forward and reverse primer for UN042 and $2.09 \mu \mathrm{L} \mathrm{H}_{2} \mathrm{O}$. The total reaction volume in both cases was $5 \mu \mathrm{L}$. Amplifications were performed under the following conditions: initial denaturation period of $94{ }^{\circ} \mathrm{C}$ for $7 \mathrm{~min}$; 35 cycles of $94{ }^{\circ} \mathrm{C}$ for $30 \mathrm{~s}, 55^{\circ} \mathrm{C}$ for $30 \mathrm{~s}$, $72{ }^{\circ} \mathrm{C}$ for $30 \mathrm{~s}$ and a final extension of $10 \mathrm{~min}$.

\subsection{Allele calling}

PCR products from each triplex reaction were diluted $1 / 20$ and $1 \mu \mathrm{L}$ of each diluted product was added to $1 \mathrm{~mL}$ formamide and $10 \mu \mathrm{L}$ LIZ DNA size standard (Applied Biosystems). Samples were run on a $3130 x l$ Genetic Analyser (Applied Biosystems) with capillary length $36 \mathrm{~cm}$ and injection time of $15 \mathrm{~s}$ at $1200 \mathrm{~V}$ for $41 \mathrm{~min}$. Resulting data files were analysed using GeneMapper3.7 (Applied Biosystems) and genotypes for each individual were constructed manually in a spreadsheet.

\subsection{Density estimation}

To estimate the density of feral colonies at each site, we used the method of Arundel et al. (2013) to generate synthetic sampling distributions based on the sample size for each location. We took the number of unique haplotypes in each sample divided by two as an estimate of the number of unique colonies present in the sample (Jaffé et al. 2010), and then determined the most likely density and a confidence interval for that density based on the number of unique colonies in the sample and the sample size (number of drones genotyped) (Arundel et al. 2013).

\subsection{Statistical analysis}

We used two-way analysis of variance (ANOVA) to examine differences in feral colony density between region and land use (i.e. undisturbed and disturbed).

\section{RESULTS}

The microsatellite loci examined were highly polymorphic (Table III). There were a total of 355 unique haplotypes ( $n=1335$ drones genotyped); therefore, the linked markers were sufficient to distinguish non-brothers.

The highest colony densities occurred at the undisturbed sites within Wyperfeld National Park: Black Flat (1.5 colonies $\mathrm{km}^{-2}$ ) and Lake Brambruk (1.0 colonies $\mathrm{km}^{-2}$ ) (Table II). Interestingly, the matching disturbed sites at Lake Albacutya and Yaapeet $(0.25$ and 0.15 colonies $\mathrm{km}^{-2}$, respectively) had some of the lowest densities of colonies in the study (Table II).

The density of colonies was significantly higher in undisturbed areas than in disturbed areas (Figure 2, $F_{1,11}=13.6, P=0.01$ ). There was a significant interaction between land use and region $\left(F_{2,11}=6.5, P=0.03\right)$. The significant interaction appears to arise because the difference in colony density between the undisturbed and disturbed sites in the Wimmera region was so large. The Barrington region had the lowest density of feral colonies and the Wimmera region had the highest density (Table II; Figure 2).

\section{DISCUSSION}

Honey bee colonies were present in all biomes and at all study sites. Colonies were present at high densities at several sites, with the highest densities in Wyperfeld National Park. The 
Table II. Estimates of the number of feral honey bee colonies at 12 sites in South East Australia.

\begin{tabular}{|c|c|c|c|c|c|c|c|}
\hline Site name & Region & $\begin{array}{l}\text { Disturbed/ } \\
\text { undisturbed }\end{array}$ & $\begin{array}{l}\text { Number } \\
\text { of } \\
\text { drones } \\
\text { sampled }\end{array}$ & $\begin{array}{l}\text { Number } \\
\text { of unique } \\
\text { haplotypes }^{\text {a }}\end{array}$ & $\begin{array}{l}\text { Estimated } \\
\text { number } \\
\text { of unique } \\
\text { colonies }\end{array}$ & $\begin{array}{l}\text { Estimated } \\
\text { density } \\
\text { (colonies/ } \\
\mathrm{km}^{-2} \text { ) }\end{array}$ & $\begin{array}{l}\text { Density } \\
\text { range } \\
\text { (colonies/ } \\
\mathrm{km}^{-2} \text { ) }\end{array}$ \\
\hline $\begin{array}{l}\text { Gloucester } \\
\text { Tops }\end{array}$ & BT & Undisturbed & 79 & 36 & 18 & 0.4 & 0.5 to 1.5 \\
\hline $\begin{array}{l}\text { Stratford } \\
\text { Park }\end{array}$ & BT & Disturbed & 123 & 28 & 14 & 0.25 & 0.1 to 1.5 \\
\hline Allyn River & BT & Undisturbed & 72 & 47 & 23.5 & 0.65 & 0.3 to 2.5 \\
\hline Monkerai & BT & Disturbed & 70 & 43 & 21.5 & 0.6 & 0.3 to 2 \\
\hline $\begin{array}{l}\text { Ben Hall's } \\
\text { Cave } \\
\text { Camp }\end{array}$ & WS & Undisturbed & 62 & 38 & 19 & 0.55 & 0.2 to 2 \\
\hline Grenfell & WS & Disturbed & 70 & 41 & 20.5 & 0.55 & 0.25 to 2 \\
\hline Holy Camp & WS & Undisturbed & 278 & 75 & 37.5 & 0.8 & 0.25 to 2 \\
\hline Tyagong & WS & Disturbed & 74 & 36 & 18 & 0.45 & 0.1 to 1.5 \\
\hline Black Flat & WR & Undisturbed & 222 & 98 & 49 & 1.5 & 0.4 to 3 \\
\hline $\begin{array}{l}\text { Lake } \\
\text { Albacutya }\end{array}$ & WR & Disturbed & 29 & 19 & 9.5 & 0.25 & 0.1 to 1.5 \\
\hline $\begin{array}{l}\text { Lake } \\
\text { Brambruk }\end{array}$ & WR & Undisturbed & 241 & 84 & 42 & 1 & 0.25 to 2.5 \\
\hline Yaapeet & WR & Disturbed & 14 & 12 & 6 & 0.15 & $<0.1$ to 0.6 \\
\hline
\end{tabular}

${ }^{\text {a }}$ See Table I for abbreviations

${ }^{b}$ The number of unique haplotypes detected in the sample of drones

estimates of colony density are smaller than those previously reported for Wyperfeld National Park via direct observation (50-150 colonies $\mathrm{km}^{-2}$, Oldroyd et al. 1995, 1997) but consistent with the results obtained by Arundel et al. (2014) (0.9 colonies $\mathrm{km}^{-2}$ ) using an indirect survey method. This difference probably arises because Oldroyd et al. $(1995,1997)$ selectively surveyed the riparian woodland where the density of colonies is likely much higher than in the surrounding dry lake beds and mallee vegetation.

Beekeeping is banned within the national parks we surveyed. However, it is possible (though unlikely) that managed apiaries outside parks contributed drones to our samples. Beekeeping is practised in the agricultural areas we surveyed, but it is unlikely that migratory apiaries were present at the times we sampled. Nonetheless, we emphasise that our estimates should be regarded as the total density of colonies present-not only feral colonies.
We found lower densities of feral colonies at the disturbed sites than at the relatively undisturbed sites in the Wimmera region and in the Barrington Tops Region. The estimates for the disturbed sites in the Wimmera region were both based on small sample sizes (Lake Albacutya $n=$ 29; Yaapeet $n=14$ drones, Table II). These low sample size sites required great effort to catch even a small number of drones. For example, at the disturbed site, Lake Albacutya, we required $10 \mathrm{~h}$ of sampling over two afternoons (15:0018:00 hours) to capture 29 drones, while at the paired undisturbed site, Lake Brambruk, we required just $10 \mathrm{~min}$ to capture 241 drones. The temperature and wind speed over these consecutive days of sampling were similar. Our difficulties in capturing drones at the disturbed sites likely reflect the low density of colonies at these sites, as suggested by the distribution of male haplotypes. Although Arundel et al. (2014) detected a significantly higher density of colonies at their disturbed Wimmera site, this can be 
Table III. Allele and haplotype diversity in drone honey bees sample in South East Australia.

\begin{tabular}{lcclll}
\hline Locus & UNEV5B & K0326 & K0362 & SV181 & UN042 \\
\hline Number of alleles & 24 & 15 & 8 & 7 & 6 \\
Alleleic diversity $-H_{\mathrm{e}}$ & 0.81 & 0.60 & 0.72 & 0.73 & 0.57 \\
\hline
\end{tabular}

$H_{e}$ expected heterozygosity

explained by the different survey methods. Arundel et al. (2014) inferred colony densities from the progeny of queens mated at each site and established that this method samples the colonies over an area of at least $177 \mathrm{~km}^{-2}$. While each DCA attracts drones from an area of $\sim 150 \mathrm{~km}^{-2}$ based on a 7-km drone flight range (Ruttner and Ruttner 1972), the limited range of attraction of 9-ODA $(100 \mathrm{~m})$ means that the drone trap method is only effective in areas of high colony density or where DCAs can be reliably located. Thus, in areas where a low density of colonies is expected, the indirect survey method using the progeny of queens mated at the survey site (Arundel et al. 2014) will tend to identify more colonies based on an increased detection range. The Stratford Park site also had a relatively low density of feral colonies in comparison with the other sites. However, this estimate was based on a sample of 123 drones and the sampling effort required was minimal.

In total, colony density was lowest in the Barrington Tops region and highest in the Wimmera region, though differences in colony density across landscapes were not significant. Given the biogeophysical differences (climate, elevation, vegetation) between the studied landscapes, the prevalence of honey bees at all sites highlights the ability of feral honey bees to succeed under a range of environmental conditions. The significant interaction between landscape and land use is largely driven by the extreme difference in feral colony densities between the undisturbed and disturbed sites in the Wimmera region. Nonetheless, there appears to be a trend for colony density to be higher in undisturbed sites compared

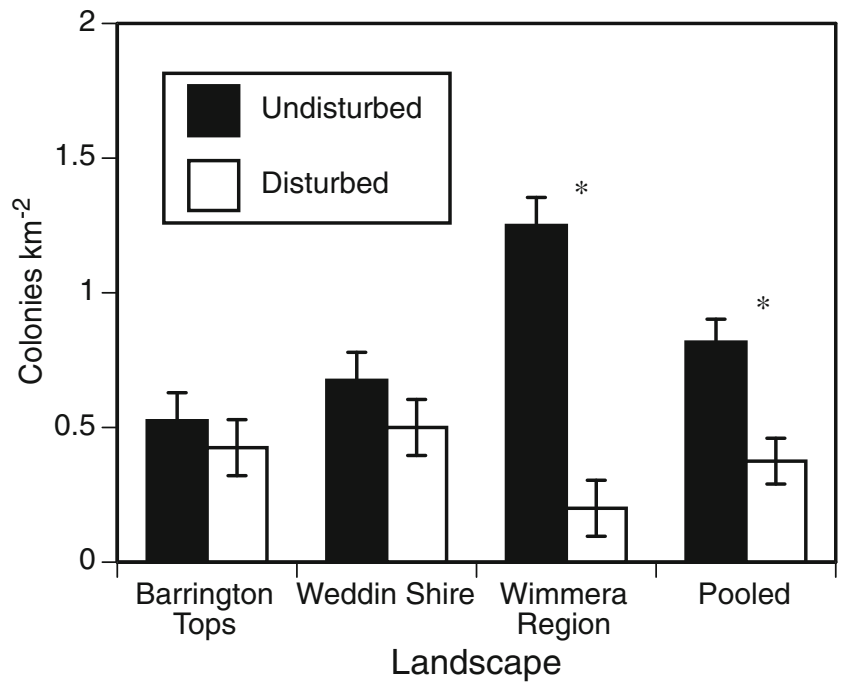

Figure 2. Mean number of feral honey bee (Apis mellifera) colonies per square kilometre in undisturbed and disturbed sites within three South East Australian landscapes, sampled in February-March, 2011. Colony density is consistently higher in undisturbed sites. $* P<0.05$, significant difference between the disturbed and undisturbed sites. Error bars are standard errors. 
with disturbed sites. We suggest that the reduced availability of nest sites is the primary cause of reduced feral colony density in disturbed sites, though reduced diversity of floral resources and pesticide usage may also contribute. An exception to this trend is urban areas, which often provide year-round floral resources and a multitude of nesting sites (Baum et al. 2008).

Our survey suggests that the density of feral colonies in South East Australia is consistent with those found internationally. Several of the studies listed in Table S1 used the same drone-trapping technique as we have here, although their reported densities differ because of the methods used to infer colony density from the number of unique haplotypes recorded at each survey site (Moritz et al. 2007, 2008; Jaffé et al. 2010). The densities measured in our study ( 0.15 to 1.5 colonies $\mathrm{km}^{-2}$ ) are comparable to the revised density estimates for these studies ( 0.1 to 3 colonies $\mathrm{km}^{-2}$ ) derived by Arundel et al. (2013).

It is presently unclear at what density feral honey bees begin to adversely affect native biota. Each habitat is characterised by abiotic and biotic factors that interact to form the structure of an ecosystem and influence the impact of an invasive species on the ecosystem. In Wyperfeld National Park, both the regent parrot (Polytelis anthopeplus) and honey bees require cavities of a suitable size for nesting. Oldroyd et al. (1994) showed that regent parrots and honey bees overlap in their use of cavities, but because cavities do not appear to be a limiting resource, competition between birds and bees for cavities is unlikely to be significant. However, excessive water extraction from the Wimmera River has meant that Outlet Creek and the 'lakes' of Wyperfeld National Park have not received flows since 1980. Without periodic flooding, mature riparian woodland vegetation suffers dieback, and there is no recruitment into the population because flooding is required for seedling establishment (George et al. 2005; Souter et al. 2010). Without changes to water flow, the number of cavities will decline over time and may cause increased competitive pressure between honey bees and regent parrots. If honey bees competitively exclude regent parrots from nest sites, there is likely to be significant decline in the population size of this already threatened bird.
The recommended number of colonies required to ensure that crops are sufficiently pollinated is $100-1000$ colonies $\mathrm{km}^{-2}$ (Delaplane and Mayer 2000; Breeze et al. 2014). Here, we have shown that even at the most populous sites, the abundance of feral honey bees is insufficient to provide adequate crop pollination over broad scales. This finding supports the view that many of our cropping systems are chronically underpollinated (Burd 1994), necessitating larger amounts of fertiliser and land under cultivation than would be required if the density of pollinators was adequate. Our study strongly suggests that paid pollination services should be expanded to ensure adequate pollination. It also highlights the importance of maintaining large, wild habitat patches interspersed in the agricultural landscape, which provide a diversity of floral and nesting resources for honey bees, native bees and native vertebrates (Oleksa et al. 2013).

\section{ACKNOWLEDGEMENTS}

This project was funded by a University of Sydney Sustainable Futures grant to Ben Oldroyd and by a RIRDC grant to Jonathan Arundel.

La densité de colonies sauvages d'abeilles (Apis mellifera) dans le sud-est de l'Australie est plus importante dans les habitats intacts que dans ceux modifiés par l'homme

Apidae / population sauvage / haplotype / microsatellite / taille de la population

Die Dichte wilder Honigbienenvölker (Apis mellifera) ist höher in gestörten als in ungestörten Habitaten Südostaustraliens

Wilde Honigbienen / Völkerdichte / Mikrosatelliten / Populationsgröße

\section{REFERENCES}

Arundel J., B.P. Oldroyd, S. Winter (2013) Modelling estimates of honey bee (Apis spp.) colony density from drones. Ecol. Model. 267, 1-10.

Arundel J., P.R. Oxley, A. Faiz, J. Crawford, S. Winter, B.P. Oldroyd (2014) Remarkable uniformity in the densities of feral honey bee Apis mellifera Linnaeus, 1758 (Hymenoptera: Apidae) colonies in South Eastern Australia. Austral Entomol. 53, 328-336. 
Baudry E., M. Solignac, L. Garnery, M. Gries, J.-M. Cornuet, N. Koeniger (1998) Relatedness among honeybees (Apis mellifera) of a drone congregation. Proc. R. Soc. Lond. B 265, 2009-2014.

Baum K.A., M.D. Tchakerian, S.C. Thoenes, R.N. Coulson (2008) Africanized honey bees in urban environments: a spatio-temporal analysis. Landsc. Urban Plan. 85, 123-132.

Benecke F.S., 2007. Commercial beekeeping in Australia, Rural Research and Development Corporation, Canbera.

Benson J.S., P.G. Richards, S. Waller, C.B. Allen (2010) New South Wales vegetation classification and assessment: part 3 plant communities of the NSW Brigalow Belt South, Nandewar and west New England Bioregions and update of NSW Western Plains and Southwestern Slopes plant communities, Version 3 of the NSWVCA database. Cunninghamia 11, 457-579.

Breeze T.D., B.E. Vaissière, R. Bommarco, T. Petanidou, N. Seraphides, et al. (2014) Agricultural policies exacerbate honeybee pollination supply-demand mismatches accross Europe, PLoS ONE 9, e82996.

Brockmann A., D. Dietz, J. Spaethe, J. Tautz (2006) Beyond 9-ODA: Sex pheromone communication in the European honey bee Apis mellifera L.. J. Chem. Ecol. $32,657-667$.

Burd M. (1994) Bateman's principle and plant reproduction: the role of pollen limitation on fruit and seed set. Bot. Rev. 60, 83-139.

Butz Huryn V.M. (1995) Use of New Zealand plants by honey bees (Apis mellifera L.): a review. New Zeal. J. Bot. 33, 497-512.

Corlett R.T. (2001) Pollination in a degraded tropical landscape: a Hong Kong case study. J. Trop. Ecol. 17, 155161.

Day D.A., B.G. Collins, R.G. Rees (1997) Reproductive biology of the rare and endangered Banksia brownii Baxter ex R. Br. (Proteaceae). Aust. J. Ecol. 22, 315.

Delaplane K.S., D.E. Mayer (2000) Crop pollination by bees, CABI Publishing, Walliford UK.

Dirk C.W. (2001) Genetic rescue of remnant tropical trees by an alien pollinator, Proc. R. Soc. Lond. B 268, 2391-2396.

Free J.B. (1970) Insect pollination of crops, Academic Press, New York.

Free J.B. (1987) Pheromones of social bees, Chapman and Hall, London.

George A.K., K.F. Walker, M.M. Lewis (2005) Population status of Eucalypt trees on the River Murray floodplain, South Australia. River Res. Appl. 21, 271-282.

Gordon J., L. Davis (2003) Valuing honeybee pollination, Rural Industries Research and Development Corporation, Canberra.

Goulson D. (2003) Effects of introduced bees on native ecosytems. Annu. Rev. Ecol. Syst. 34, 1-26.

Goulson D., L.C. Derwent (2004) Synergistic interactions between an exotic honeybee and an exotic weed: pollination of Lantana camera in Australia. Weed Res. 44, 195-202.

Gross C.L. (2001) The effect of introduced honeybees on native bee visitation and fruit-set in Dillwynia juniperina (Fabaceae) in a fragmented ecosystem. Biol. Conserv. 102, 89-95.

Gross C.L., D. Mackay (1998) Honeybees reduce fitness in the pioneer shrub Melastoma affine (Melastomataceae). Biol. Conserv. 86, 169-178.

Hopkins I. (1886) Illustrated Australasian Bee Manual, I Hopkins, Auckland.

Jaffé R., V. Dietemann, M.H. Allsopp, C. Costa, R.M. Crewe, et al. (2010) Estimating the density of honeybee colonies across their natural range to fill the gap in pollinator decline consensus. Conserv. Biol. 24, 583593.

Jensen A.B.., K.A. Palmer, N. Chaline, N.E. Raine, A. Tofilski, S.J. Martin, B.V. Pedersen, J.J. Boomsma, F.L.W. Ratnieks (2005) Quantifying honey bee mating range and isolation in semi-isolated valleys by DNA microsatellite paternity analysis. Conserv. Genet. 6, 527-537.

Koeniger G., N. Koeniger, H. Pechhacker, F. Ruttner, S. Berg (1989) Assortative mating in a mixed population of European honeybees. Apis mellifera ligustica and Apis mellifera carnica. Insectes Soc. 36, 129-138.

Lomov B., D.A. Keith, D.F. Hochuli (2010) Pollination and plant reproductive success in restored urban landscapes dominated by a pervasive exotic pollinator. Landsc. Urban Plann. 96, 232-239.

Loper G.M., W.W. Wolf, O.R. Taylor (1992) Honey bee drone flyways and congregation areas - radar observations. J. Kansas Entomol. Soc. 65, 223-230.

McGregor S.E. (1976) Insect pollination of cultivated crop plants, United States Department of Agriculture, Washington.

Moritz R.F.A., F.B. Kraus, P. Kryger, R.M. Crewe (2007) The size of wild honeybee populations (Apis mellifera) and its implications for the conservation of honeybees. J. Insect Conserv. 11, 391-397.

Moritz R.F.A., V. Dietemann, R. Crewe (2008) Determining colony densities in wild honeybee populations (Apis mellifera) with linked microsatellite DNA markers. J. Insect Conserv. 12, 455-459.

Neumann P., J.P. van Praagh, R.F.A. Moritz, J.H. Dustmann (1999) Testing reliability of a potential island mating apiary using DNA microsatellites. Apidologie 30, 257-276.

NPWS, 1995. Weddin Mountains National Park, plan of management, NSW National Parks and Wildlife Service, Sydney.

NPWS, 2004. Killarney Nature Reserve: plan of management, NSW National Parks and Wildlife Service, Sydney.

NPWS, 2010. Barrington Tops National Park, Mount Royal National Park, and Barrington Tops State Conservation Area plan of management, NSW National Parks and Wildlife Service, Sydney. 
Oldroyd B.P. (1999) Coevolution while you wait: Varroa jacobsoni, a new parasite of western honeybees. Trends Ecol. Evol. 14, 312-315.

Oldroyd B.P., S.H. Lawler, R.H. Crozier (1994) Do feral honey bees (Apis mellifera) and regent parrots (Polytelis anthopeplus) compete for nest sites? Aust. J. Ecol. 19, 444-450.

Oldroyd B.P., A. Smolenski, S. Lawler, A. Estoup, R. Crozier (1995) Colony aggregations in Apis mellifera . Apidologie 26, 119-130.

Oldroyd B.P., E.G. Thexton, S.H. Lawler, R.H. Crozier (1997) Population demography of Australian feral bees (Apis mellifera). Oecologia 111, 381-387.

Oleksa A., R. Gawroński, A. Tofilski (2013) Rural avenues as a refuge for feral honey bee population. J. Insect Conservation 17, 465-472.

Paini D.R., M.R. Williams, J.D. Roberts (2005) No shortterm impact of honey bees on the reproductive success of an Australian native bee. Apidologie 36, 613-621.

Paton D.C. (1993) Honeybees in the Australian environment. BioScience 43, 95-103.

Paton D.C. (1996) Overview of the impacts of feral and managed honeybees in Australia, Australian Nature Conservation Agency, Canberra.

Paton D.C. (1997) Honey bees Apis mellifera and the disruption of plant-pollinator systems in Australia. Vic. Nat. 114, 23-29.

Peer D.F. (1957) Further studies on the mating range of the honeybee Apis mellifera, Can. Entomol. 89, 108-110.

Richardson D.M., N. Allsopp, C.M. D’Antonio, S.J. Milton, M. Rejmanek (2000) Plant invasions - the role of mutualisms. Biol. Rev. 75, 65-93.

Rinderer T.E., B.P. Oldroyd, A.M. Frake, L.I. deGuzman, A.L. Bourgeois (2013) Responses to Varroa destructor and Nosema ceranae by several commercial strains of Australian and North American honey bees (Hymenoptera: Apidae). Aust. J. Entomol. 51, 156-163.

Roubik D.W., Ed. 1995. Pollination of cultivated plants in the tropics, Food and Agriculture Organization of the United Nations, Rome.

Roubik D.W., R. Villanueva-Gutierrez (2009) Invasive Africanized honey bee impact on native solitary bees: a pollen resource and trap nest analysis, Biol. J. Linn. Soc. 98, 152-160.

Ruttner H., F. Ruttner (1972) Untersuchungen über die Flugaktivität und das Paarungsverhalten der Drohnen.
V. - Drohnensammelplätze und Paarungsdistanz. Apidologie 3, 203-232.

Saunders D.A., G.T. Smith, I. Rowley (1982) The availability and dimensions of tree hollows that provide nest sites for cockatoos (Psittaciformes) in Western Australia. Aust. J. Wildl. Manage. 9, 541-546.

Simpson S.R., C.L. Gross, L.X. Silberbauer (2005) Broom and honeybees in Australia: an alien liaison. Plant Biol. 7, 541-548.

Solignac M., D. Vautrin, A. Loiseau, F. Mougel, E. Baudry, A. Estoup, L. Garnery, M. Haberl, J.-M. Cornuet (2003) Five hundred and fifty microsatellite markers for the study of the honeybee (Apis mellifera L.) genome. Mol. Ecol. Notes 3, 307-311.

Souter N.J., S. Cunnigham, S. Little, T. Wallace, B. McCarthy, M. Henderson (2010) Evaluation of a visual assessment method for tree condition of eucalypt floodplain forests. Ecol. Manage. Rest. 11, 210-214.

Sugden E.A., R.W. Thorpe, S.L. Buchmann (1996) Honey bee-native bee competition: focal point for environmental change and apicultural response in Australia. Bee Wld. 77, 26-44.

Taylor O.R., G.A. Rowell (1988) Drone abundance, queen flight distance, and the neutral mating model for the honey bee, Apis mellifera, in: Needham G.R., Page R.E.J., Delfenado-Baker M.. Bowman C.E. (Eds.), Africanized honey bees and bee mites, Ellis Horwood, Chichester, pp. 173-183.

Taylor G., R.J. Whelan (1988) Can honeybees pollinate Grevillea? Aust. Zool. 24, 193-196.

Vaughton G. (1996) Pollination disruption by European honeybees in the Australian bird-pollinated shrub Grevillea barklyana (Proteaceae). Plant Syst. Evol. 200, 89-100.

Walsh P.S., D.A. Metzger, R. Higuchi (1991) Chelex (R)100 as a medium for simple extraction of DNA for PCR-based typing from forensic material. Biotechniques 10, 507.

Williams J.L. (1987) Wind-directed pheromone trap for drone honey bees (Hymenoptera: Apidae). J. Econ. Entomol. 80, 532-536.

Winston M.L. (1987) The biology of the honey bee, Harvard University Press, Cambridge.

Wood M.S., R.L. Wallis (1998) Potential competition for nestboxes between feral honeybees and sugar gliders at Tower Hill state game reserve. Vic. Nat. $115,78-80$. 